Encounters on Education

Volume 4, Fall 2003 pp. 47 - 64

\title{
What kind of citizen? Political choices and educational goals
}

\author{
J oel Westheimer \\ University of Ottawa \\ J oseph Kahne \\ Mills College
}

\begin{abstract}
The notion of democracy occupies a privileged place in our society. Educators and policymakers are increasingly pursuing a broad variety of programs that aim to promote democracy through civic education, service learning, and other pedagogies. The nature of their underlying beliefs, however, differs. "W hat K ind of C itizen?" calls attention to the spectrum of ideas represented in education programs about what good citizenship is and what good citizens do. 0 ur argument derives from an analysis of both democratic theory and a two year study of educational programs in the U.S. that aim to promote democracy. The study employed a mixed-methods approach, combining qualitative data from observations and interviews with analysis of program documents and quantitative analysis of pre/post survey data. We detail three conceptions of the "good" citizen: personally responsible, participatory, and justice oriented that emerged from literature analysis and from our study. We argue that these three conceptions embody significantly different beliefs regarding the capacities and commitments citizens need in order for democracy to flourish; and they carry significantly different implications for pedagogy, curriculum, evaluation, and educational policy. We underscore the political implications of education for democracy and suggest that the narrow and often ideologically conservative conception of citizenship embedded in many current efforts at teaching for democracy reflects not arbitrary choices but rather political choices with political consequences.
\end{abstract}

Key words: Citizenship, education, democracy, justice, civic engagement

\section{RESUMEN}

La noción de democracia ocupa un lugar privilegiado en nuestra sociedad. Educadores y gobernantes llevan adelante con creciente intensidad una gran variedad de programas para promover la democracia a través de educación cívica, aprendizaje-servicio, y otras estrategias pedagógicas. Sin embargo, la natural eza de los supuestos subyacentes no es la misma en todos los casos. "¿Q uétipo de ciudadano?" Ilama la atención sobre el espectro de ideas, representadas en los programas educativos, sobre lo que es la buena ciudadanía es y sobre lo que hacen los buenos ciudadanos. N uestro argumento deriva del análisis de las teorías sobre la democracia y de un estudio de dos años sobre programas educativos para la promoción de la democracia. El estudio empleó varios métodos, combinando datos cualitativos con observaciones, entrevistas, análisis de documentos y análisis cuantitativo de 'pre-post' datos obtenidos a través de un cuestionario. En nuestro estudio 
identificamos tres concepciones de "buen ciudadano": personal mente responsable, participativo, y orientado a la justicia. Estas tres concepciones representan diferentes creencias sobre las capacidades y los compromisos ciudadanos requeridos para el florecimiento de la democracia, y tienen diferentes implicaciones pedagógicas, curriculares, evaluativas y de política educativa. En este trabajo subrayamos las implicaciones políticas de la educación para la democracia y sugerimos que la concepción estrecha y frecuentemente de inspiración ideológica conservadora que caracteriza a muchas iniciativas educativas actuales refleja opciones que no son arbitrarias; por el contrario, son opciones políticas con consecuencias políticas.

Descriptores: Ciudadanía, educación, democracia, justicia, participación ciudadana

\section{RÉSUMÉ}

La notion de démocratie occupe une place privilégiée dans notre société. Les éducateurs et les personnes responsables des politiques poursuivent de plus en plus une grande variété de programmes qui visent a promouvoir la démocratie par l'éducation civique, l'apprentissage du service et par d'autres pédagogies. Toutefois la nature de leurs convictions sous-jacentes diffère. "Q uelle sorte de citoyen?" attire l'attention sur la gamme d'idées représentées dans les programmes d'éducation concernant ce qu'est la bonne citoyenneté et ce que font les bons citoyens. $N$ otre argument découle et d'une anal yse de la théorie démocratique et d'une étude de deux ans de programmes éducatifs qui visent à promouvoir la démocratie. L'étude emploie une approche constituée de méthodes mixtes, combinant des données qualitatives d'observations, d'interviews avec l'analyse de documents de programmes et l'analyse quantitative de données de sondages pré/post. N ous détaillons trois conceptions du "bon" citoyen: personnellement responsable, participatif, et orienté vers la justice, qui emergent de l'analyse d'écrits et de notre étude. Nous soutenons que ces trois conceptions incarnent de façon significative différentes convictions concernant les capacités et les engagements dont les citoyens ont besoin pour que la démocratie s'épanouisse; et elles portent des implications significativement différentes pour la pédagogie, le curriculum, l'éval uation et la potitique éducative. N ous soulignons les implications politiques de l'éducation pour la démocratie et nous suggérons que la conception étroite et souvent idéologiquement conservatrice de la citoyenneté qui est enracinée dans beaucoup d'efforts actuels d'enseignement en vue de la démocratie reflète non des choix arbitraires mais plutôt des choix politiques portant des conséquences politiques.

Mots-cléfs: Citoyenneté, éducation, démocratie, justice, engagement civique

N I985, BILL BENNETt, then Secretary of Education under Ronald Reagan, wrote the following:

A democracy depends on schools that help to foster a kind of character which respects the law and... respects the value of the individual." (1985)

That same year, in his book The Politics of Education: Culture, Power and Liberation, Paulo Freire wrote that,

D emocracy requires oppressed groups to develop political determination, that is, to organize and mobilize in order to achieve their own objectives. Education can make possible such a democracy. (1985)

The next year, Albert Shanker had this to say in a speech called "Education and D emocratic Citizenship":

H ow can we fail to build a world in which the rights due to every human being from birth are respected? In order to build this world... we must [have schools] teach democracy. (1986) 
Finally, U.S. President G eorgeW. Bush recently established a N ational Veterans Awareness week and launched a new school program he noted would rekindle our democratic spirit. $\mathrm{H}$ ecalled the program "Lessons of Liberty" in which, and this is the President talking,

Veterans will visit elementary and high school classrooms to teach the ideals of democracy and freedom that American servicemen have defended for over two centuries. (2001)

Each of these quotations takes seriously the idea that schools are essential for democracy. Yet Bennett, Freire, Shanker, and Bush each provide their own sense of what democracy requires and how schools can help us to strengthen their respective - and often competing - visions of a democratic society. When educators, policymakers, politicians, and community activists pursue democracy, they do so in many different ways and towards many different ends.

For many educators, making the case for democracy and the important role for schools in pursuing it is not difficult. Political scientists and civic educators are both familiar with statistics showing that voting rates have dropped precipitously and that the biggest declines are among young people. $M$ any know that political participation such as working for a political party is at a 40 year low (Saguaro Seminar, 2000). And targeting what people do not know about civics remains a favorite pastime of not only D avid Letterman but also educators and politicians: one study, by the $\mathrm{N}$ ational Constitution Center, found that only $38 \%$ of respondents could name all three branches of government while a separate poll conducted two years earlier found that $59 \%$ of all Americans could name the three stooges (D udley $\&$ Gitelson, 2002). Recent debates about domestic security, individual liberties, and foreign policy have further spurred educators to reexamine the role of schools in educating students to be thoughtful and engaged citizens. Everyone now seems to believe that citizenship is important.

In fact, as long as we remain at the level of rhetoric we can get most educators to agree that teaching how to be a good citizen is important. But when we get specific about what democracy requires and about what kind of school curricula will best promote it, much of that consensus falls away. For some, a commitment to democracy is a promise to protect liberal notions of freedom, while for others democracy is primarily about equality or equality of opportunity. For some, civil society is the key, while for others, free markets are the great hope for a democratic society. For some, good citizens in a democracy volunteer, while for others they take active parts in political processes by voting, protesting, and working on political campaigns.

It is not surprising, then, that the growing number of educational programs that seek to further democracy by nurturing "good" citizens embody a similarly broad variety of goals and practices. We titled this article "W hat Kind of Citizen?" to call attention to the spectrum of ideas about what good citizenship is and what good citizens do that are embodied by democratic education programs nationwide. We added the subtitle "T he Politics of Education for D emocracy" to reflect our belief that the narrow and often ideologically conservative conception of citizenship embedded in many current efforts at teaching for democracy doesn't reflect arbitrary choices or pedagogical limitations but rather political choices with political consequences. 
We spent two years studying ten programs that shared a basic set of priorities: they all hoped to teach good citizenship (through civics curriculum, service learning, and other means) by engaging students in analysis and action on community issues. But the different curricula we examined affected students in a variety of ways, not all of which were shared across programs. M oreover, the meanings leaders of these programs brought to notions of citizenship and to the term "democratic values" varied significantly.

In what follows, we detail three conceptions of citizenship that emerged from our analysis of both democratic theory and program goals and practices. We al so use two brief examples from two of the ten programs we studied to illustrate the need for more discriminating analyses of programs that seek to nurture good citizens. We will be making the case that educators need to take into account the varied notions of citizenship reflected in programs and that decisions we make in designing as well as researching these programs are, in fact, political.

\section{What kind of citizen?}

Philosophers, historians and political scientists have long debated which conceptions of citizenship would best advance democracy (see, for example, Kaestle, 2000; M iller, 1995; Schudson, 1998; Smith, 1997). Indeed, as Connolly (1983) has argued, conceptions of democracy and citizenship have been and will likely always be debated - no single formulation will triumph. Even though the work of John D ewey has perhaps done the most to shape dialogues around education and democracy, scholars and practitioners have interpreted his ideas in multiple ways, so no single conception emerges. In large part, this diversity of perspectives occurs because the stakes are so high. C onceptions of "good citizenship" imply conceptions of the good society (Parker, 1996).

The diverse perspectives on citizenship and the significant implications of these differences are also quite clear when one examines dialogues that surround educational efforts to promote democratic aims. This vital intellectual discourse does not provide anything close to consensus (i.e. N iemi \& Junn, 1998; Soder et al., 2001; Tarcov, 1996). For example, Walter Parker (1996) describes three very different conceptions of citizen education for a democratic society: "traditional," "progressive," and "advanced." H e explains that traditionalists emphasize an understanding of how government works (how a bill becomes a law, for example) and traditional subject area content as well as commitments to core democratic values - such as freedom of speech or liberty in general (see, for example, Butts, 1988). Progressives share a similar commitment to this knowledge, but they embrace visions like "strong democracy" (Barber, 1984) and place a greater emphasis on civic participation in its numerous forms (see, for example, H anna, 1936; N ewmann, 1975). Finally, "advanced" citizenship, according to Parker, is one that builds on the progressive perspective but adds careful attention to inherent tensions between pluralism and assimilation or to what C harles Taylor, labels the "politics of recognition" (1994, cited in Parker (1996)).

0 thers place a greater emphasis on the need for social critique and structural change. They argue that educators should promote what Jesse Goodman (1992) calls "critical democracy," Ira Shor (1992) calls "empowering education", and Paulo Friere (1970) calls a "Pedagogy of the 0 ppressed." 
In striking contrast with these perspectives is the relatively conservative vision of citizenship education put forward by those who emphasize the connection between citizenship and character (Bennett, 1995; 1998; Bennett, Cribb, \& Finn, 1999). Rather than viewing the problems in need of attention as structural, they emphasize problems in society caused by personal deficits. This view harkens back to what Shudson (1998) describes as a vision of 'colonial citizenship' "built on social hierarchy and the traditions of public service, personal integrity, [and] charitable giving" (294).

\section{Three kinds of citizens}

O ur framework aims to order some of these perspectives by grouping three differing kinds of answers to a question that is of central importance for both practitioners and scholars: What kind of citizen do we need to support an effective democratic society? In mapping the terrain that surrounds answers to this question, we found that three visions of "citizenship" were particularly hel pful in making sense of the variation: the personally responsible citizen; the participatory citizen; and the justice oriented citizen (seetable 1).

These three categories were chosen because they satisfied our two main criteria: 1) they aligned well with prominent theoretical perspectives described above, and 2) they articulate ideas and ideals that resonate with practitioners (teachers, administrators, and curriculum designers). To that end, we consulted with both the 10 teams of educators whose work we studied and with other leaders in the field in an effort to create categories and descriptions that aligned well with and communicated clearly their differing priorities².

A caveat: although these three categories were chosen to highlight important differences in the ways educators conceive of democratic educational aims, we do not mean to imply that a given program might not simultaneously further more than one of these agendas. These categories were not designed to be mutually exclusive. At the same time, we believe that drawing attention to the distinctions between these visions of citizenship is important. It highlights the importance of examining the underlying goals and assumptions that drive different educational programs in design and practice. 
Tablel: Kinds of Citizens

Description

\begin{tabular}{|c|c|c|}
\hline \multirow{6}{*}{$\begin{array}{l}\text { Personally ReqponsibleCitizen } \\
\text { Acts responsibly in his/her } \\
\text { community } \\
\text { Works and pays taxes } \\
\text { O beys laws } \\
\text { Recycles, gives blood } \\
\text { Volunteers to lend a hand in } \\
\text { times of crisis }\end{array}$} & Partidipatory Citizen & JusticeOriented Citizen \\
\hline & $\begin{array}{l}\text { Active member of community } \\
\text { organizations and/or improve- } \\
\text { ment efforts }\end{array}$ & $\begin{array}{l}\text { Critically assesses social, political, } \\
\text { and economic structures to see } \\
\text { beyond surface causes }\end{array}$ \\
\hline & \multirow{2}{*}{$\begin{array}{l}\text { O rganizes community efforts to } \\
\text { care for those in need, promote } \\
\text { economic development, or clean } \\
\text { up environment }\end{array}$} & $\begin{array}{l}\text { Seeks out and addresses areas of } \\
\text { injustice }\end{array}$ \\
\hline & & \multirow{3}{*}{$\begin{array}{l}\text { Knows about social movements } \\
\text { and how to effect systemic change }\end{array}$} \\
\hline & $\begin{array}{l}\text { Knows how government agencies } \\
\text { work }\end{array}$ & \\
\hline & $\begin{array}{l}\text { Knows strategies for accomplish- } \\
\text { ing collective tasks }\end{array}$ & \\
\hline \multicolumn{3}{|l|}{ SampleAction } \\
\hline Contributes food to a food drive & H elps to organize a food drive & $\begin{array}{l}\text { Explores why people are hungry } \\
\text { and acts to solve root causes }\end{array}$ \\
\hline \multicolumn{3}{|l|}{ Core Assumptions } \\
\hline $\begin{array}{l}\text { To solve social problems and } \\
\text { improve society, citizens must } \\
\text { have good character; they must } \\
\text { be honest, responsible, and } \\
\text { law-abiding members of the } \\
\text { community }\end{array}$ & $\begin{array}{l}\text { To solve social problems and } \\
\text { improve society, citizens must } \\
\text { actively participate and take lead- } \\
\text { ership positions within estab- } \\
\text { lished systems and community } \\
\text { structures }\end{array}$ & $\begin{array}{l}\text { To solve social problems and } \\
\text { improve society, citizens must ques- } \\
\text { tion and change established systems } \\
\text { and structures when they reproduce } \\
\text { patterns of injustice over time }\end{array}$ \\
\hline
\end{tabular}

\section{The personally responsible citizen}

The personally responsible citizen acts responsibly in his/her community by, for example, picking up litter, giving blood, recycling, volunteering, and staying out of debt. The personally responsible citizen works and pays taxes, obeys laws, and helps those in need during crises such as snowstorms or floods. The personally responsible citizen contributes to food or clothing drives when asked and volunteers to help those less fortunate whether in a soup kitchen or a senior center. S/he might contribute time, money, or both to charitable causes.

Both those in the character education movement and many of those who advocate community service would emphasize this individualistic vision of good citizenship. Programs that seek to develop personally responsible citizens hopeto build character and personal responsibility by emphasizing honesty, integrity, self-discipline, and hard work (M ann, 1838; and currently proponents such as Lickona, 1993; Wynne, 1986). The Character Counts! C oalition, for example, advocates teaching students to "treat others with respect... deal peacefully with anger... be considerate of the feelings of others... follow the Golden Rule... use good manners" and so on. They want students not to "threaten, hit, or hurt anyone [or use] bad language" (Character Counts!, 1996). O ther programs that seek to develop personally responsible citizens hope to nurture compassion by engaging students in volunteer activities. Asillustrated in the mission of the Points of Light Foundation, these programs hope to "help solve serious social problems" by "engag[ing] more people more effectively in volunteer service" (Points of Light Foundation, 2003). 


\section{The participatory citizen}

0 ther educators see good citizens as those who actively participate in the civic affairs and the social life of the community at local, state, and national levels. We call this kind of citizen the participatory citizen. Proponents of this vision emphasize preparing students to engage in collective, community-based efforts. Educational programs designed to support the development of participatory citizens focus on teaching students about how government and other institutions (eg. community based organizations, churches) work and about the importance of planning and participating in organized efforts to care for those in need, for example, or in efforts to guide school policies. Skills associated with such collective endeavors - such as how to run a meeting - are also viewed as important (N ewmann, 1975; also see Verba et al., 1995 for an empirical analysis of the importance of such skills and activities). While the personally responsible citizen would contribute cans of food for the homeless, the participatory citizen might organize the food drive.

In the tradition of D eTocqueville, proponents of participatory citizenship argue that civic participation transcends particular community problems or opportunities. It also develops relationships, common understandings, trust, and collective commitments. This perspective, like Benjamin Barber's notion of "strong democracy," adopts a broad notion of the political sphere- one in which citizens "with competing but overlapping interests can contrive to live together communally" (1984, p. 118).

Similar themes have been emphasized throughout this nation's history. Dewey (1916) put forward a vision of "D emocracy as a Way of Life" and emphasized participation in collective endeavors. To support the efficacy of these collective efforts, he also emphasized commitments to communication, experimentation, and scientifically informed dialogues. Such commitments were also prevalent in the educational writings of the $\mathrm{N}$ ation's founders. Thomas J efferson, Benjamin Franklin, and others viewed informed participation in civic life as a fundamental support for a democratic society and saw education as a chief means for furthering this goal (Pangle $\&$ Pangle, 1993).

\section{The justice oriented citizen}

O ur third image of a good citizen is, perhaps, the perspective that is least commonly pursued. We refer to this view as the justice oriented citizen because advocates of these priorities use rhetoric and analysis that calls explicit attention to matters of injustice and to the importance of pursuing social justice. Although educators aiming to promote justice oriented citizens may well employ curriculum that makes political issues more explicit than those who emphasize personal responsibility or participatory citizenship, the focus on social change and social justice does not imply an emphasis on particular political perspectives, conclusions, or priorities. Rather, justice oriented citizens critically assess social, political, and economic structures and consider collective strategies for change that challenge injustice and, when possible, address root causes of problems. The vision of the justice oriented citizen shares with the vision of the participatory citizen an emphasis on collective work related to the life and issues 
of the community. Its emphasis on responding to social problems and to structural critique make it somewhat different, however. Building on perspectives like those of Freire, Shor, and Goodman noted earlier, educational programs that emphasize social change seek to prepare students to improve society by critically analyzing and addressing social issues and injustices. These programs are less likely to emphasize the need for charity and volunteerism as ends in themselves and more likely to teach about social movements and how to effect systemic change (See, for example, Isaac, 1992; Bigelow and D iamond, 1988). While those who support the development of participatory citizens might emphasize developing students' skills and commitments so that they could and would choose to organize the collection of clothing for members of the community who can't afford it, those who seek to support the development of justice oriented citizens would emphasize helping students challenge structural causes of poverty and devise possible responses. In other words, if participatory citizens are organizing the food drive and personally responsible citizens are donating food, justice oriented citizens are asking why people are hungry and acting on what they discover. That today's citizens are "bowling alone" (Putnam, 2000) would worry those focused on civic participation. Those who emphasize social justice, however, would worry more that when citizens do get together, they often fail to focus on or to critically analyze the social economic, and political structures that generate problems.

The strongest proponents of this perspective were likely the Social Reconstructionists who gained their greatest hearing between the two world wars. Educators like $\mathrm{H}$ arold Rugg (1921) argued that the teaching of history in particular and the school curriculum more generally should be developed in ways that connect with important and enduring social problems. George Counts (1932) asked, "D are the School Build a N ew Social O rder?" He wanted educators to critically assess varied social and economic institutions while also "engag[ing] in the positive task of creating a new tradition in American life" (262). These educators emphasized that truly effective citizens needed opportunities to analyze and understand the interplay of social, economic, and political forces and to take part in projects through which they might develop skills and commitments for working collectively to improve society.

\section{Conflicting prionities}

Is it possible to pursue all three of these visions? Perhaps. Might there be conflicts? Yes. Certainly participatory citizens or those committed to justice can simultaneously be dependable or honest - at least we hope so - therefore conflicts between some priorities associated with personal responsibility and those of participation and justice are not guaranteed. H owever, there may also be conflicts and these conflicts are likely to be significant ones. The emphasis placed on individual character and behavior can obscure the need for collective and often public sector initiatives. 


\section{Citizenship without politics: Service and character, but not democracy}

A vast majority of school-based programs embrace a vision of citizenship devoid of politics; they often promote service but not democracy. They share an orientation toward volunteerism and charity and away from teaching about social movements, social transformation, and systemic change. These programs privilege individual acts of compassion and kindness over social action and the pursuit of social justice.

We find personal responsibility an inadequate response to the challenges of educating a democratic citizenry. First, the emphasis placed on individual character and behavior obscures the need for collective and often public sector initiatives; second, this emphasis distracts attention from analysis of the causes of social problems; and third, volunteerism and kindness are put forward as ways of avoiding politics and policy.

As a way of illustrating what we see as the limitations of personally responsible citizenship, recall the central tenets of the C haracter C ounts! C oalition. C ertainly honesty, integrity, and responsibility for one's actions are valuable character traits for good neighbors and citizens. But, on their own, these traits are not inherently about democracy. To the extent that these traits detract from other important democratic priorities, they hinder rather than make possible democratic participation and change. For example, a focus on loyalty or obedience (common components of character education as well) work against the kind of critical reflection and action many assume are essential in a democratic society. Personal responsibility must be considered in a broader social context or it risks advancing mere civility or docility instead of democracy. Indeed, government leaders in a totalitarian regime would be as delighted as leaders in a democracy if their young citizens learned the lessons put forward by many of the proponents of personally responsible citizenship: don't do drugs; show up to school; show up to work; give blood; help others during a flood; recycle; pick up litter; clean up a park; treat old people with respect. Chinese leader Jiang Zemin along with $\mathrm{G}$ eorge W. Bush (and Al Gore, for that matter) would argue that these are desirable traits for people living in a community. But they are not about democratic citizenship.

Reinforcing these criticisms of an exclusive focus on personally responsible citizenship, a study commissioned by the N ational Association of Secretaries of State (1999) found that less than 32 percent of eligible voters between the ages of 18 and 24 voted in the 1996 presidential election (in 1972, the comparable number was 50 percent), but that a whopping 94 percent of those aged 15-24 believed that "the most important thing I can do as a citizen is to help others" (also see Sax, et al., 1999). In a very real sense, youth seem to be "learning" that citizenship does not require government, politics, or even collective endeavors.

In contrast to advocates of personally responsible citizenship, some political theorists, sociologists, historians, and educators have championed the importance of civic participation. In M aking D emocracy Work (1993), for example, Robert Putnam argues that participation in civic life and the development of "social capital" are essential. $\mathrm{H}$ arry Boyte and $\mathrm{N}$ an Kari make similar arguments in their case for the "democratic 
promise of public work" (1996). They join a growing number of educators who want to teach the knowledge and skills necessary for civic engagement in community affairs. Advocates of participatory citizenship want students to be schooled in both the broad and minute challenges specific to democratic participation.

Placing social justice at the center of their arguments, other educators and theorists stress that critical analysis and liberatory pedagogy are essential for democratic education. Citizens, according to this view, need not only skills associated with participation but also those required to critically analyze and act on root causes of social problems and inequities. These actions include forms of participation that challenge existing power structures and focus on social change (see, for example, Shor, 1992 and Ayers et al., 1998).

O ften, democratic theorists blend commitments to participation with commitments to justice. From the standpoint of supporting the development of democratic communities, combining these commitments is rational. D eveloping commitments for civic participation and social justice as well as fostering the capacities to fulfill these commitments will support the development of a more democratic society. We should be wary of assuming that commitments to participatory citizenship and to justice necessarily align, however. These two orientations have potentially differing implications for educators. While pursuit of both goals may well support development of a more democratic society, it is not clear whether making advances along one dimension will necessarily further progress on the other. D o programs that support civic participation necessarily promote students' capacities for critical analysis and social change? Conversely, does focusing on social justice provide the foundation for effective and committed civic actors? Or might such programs support the development of armchair activists who have articulate conversations over coffee, without ever acting? We now turn to these questions.

O ur empirical investigation of this topic focuses on the subtle and not so subtle differences between programs that emphasize participation and those that emphasize justice. We do this for two reasons. First, due to shortcomings of the personally responsible model as a means of developing citizens, none of the programs funded by the foundation that supported our study emphasized this approach. M oreover, as noted earlier, a significant body of work al ready addresses the conflicts and limitations of equating personal responsibility with democratic citizenship.

Two of the programs we studied illustrated broad differences in their civic and democratic priorities and exemplify the tensions these differences raise for educators. Both programs worked with classes of high school students and both initiatives were designed to support the development of democratic and civic understandings and commitments. But their goals and strategies differed. The first, which we call M adison County Youth in Public Service, aims to develop participatory citizens; the second, which we call Bayside Students for Justice, aims to develop justice-oriented citizens. 


\section{Developing participatory citizens: Madison County Youth in Public Service}

M adison C ounty Youth in Public Service is run by two social studies teachers in a rural East C oast community. These teachers taught a condensed and intensified version of a standard government course during the first semester of the academic year to make space for projects in the community. D uring the second semester, they placed students in small teams where they worked on public service projects in their country's administrative offices. O ne group of students investigated whether citizens in their community would prefer curbside trash pickup that was organized by the county; another group explored the development of a five year plan for the fire and rescue department. For each project, students had to collect and analyze data, interact with government agencies, write a report, and present their findings in a formal hearing in front of the county's Board of Supervisors.

The teachers of Youth in Public Service believed that placing students in internships where they worked on meaningful projects under the supervision of committed rolemodels would:

- teach students how government worked;

- help students recognize the importance of being actively involved in community issues; and

- providestudents with the skills required for effective and informed civic involvement.

M adison County Youth In Public Service was quite successful at achieving those goals. We saw evidence (both quantitative and qualitative) that, by engaging students in projects in the community, M adison County Youth in Public Service had significant success making learning relevant to students and conveying practical knowledge about how to engage in community affairs. It developed in students the desire to participate in civic affairs and a sense that they can make a difference in the lives of others.

We saw little evidence, however, that students learned about political issues related to interest groups and the political process, the causes of poverty, different groups' need for health care, or the fairness of different forms of taxation (even though two projects focuses on issues related to health care and taxation). Students focused on particular programs and policies and aimed for "technocratic/value neutral" analysis. Accordingly, our data show that the curriculum did not appear to change students' interest in politics or their perspective on issues related to systemic causes of social problems. M ore on this later.

\section{Developing justice oriented citizens: Bayside Students for J ustice}

A second program took place in a comprehensive urban high school on the West Coast. Inspired by the United N ations' D eclaration of Human Rights, teachers in this school implemented the Students for Justice curriculum with students diverse in ethnicity, language, and socioeconomic status, 40 percent of whom were living in public housing. 
Bayside Students for Justice aimed to develop community activists. As one of the teachers for this program put it, "M y goal is to turn students into activists [who are] empowered to focus on things that they care about in their own lives and to... show them avenues that they can use to achieve real social change, profound social change." The program advanced a justice oriented vision of citizenship seeking to teach students how to address structural issues of inequity and injustice and bring about social change.

The teachers of the Bayside Students for J ustice program believed that having students seek out and address areas of injustice in society would:

- sensitize students to recognize injustice;

- teach students to critically assess root causes of social problems; and

- provide students with an understanding of how to change established systems and structures.

Some students, for example, investigated the lack of access to a local health center for women; others sought ways of challenging a Senate bill that would put students and their parents in jail for truancy and would try juveniles as adults for certain crimes; other students studied violence in their community. In contrast to programs that seek to teach that "one person can make a difference," Bayside Students For Justice emphasized the need to address social problems collectively. In interviews and written assignments for class, students demonstrated their understanding of a collective rather than individual vision for effecting change.

Survey results reflected Bayside's emphasis on social change. Surveys of Bayside students revealed significant increases on items measuring interest in politics and structural explanations for poverty - scales on which Youth In Public Service students showed no change. Bayside students also indicated an increased sense of civic agency and an increased belief that government had a responsibility to help those in need.

Unlike the Youth In Public Service students, however, Bayside students did not demonstrate much specific knowledge about particular community groups or about the technical challenges and possibilities associated with specific policies and initiatives.

\section{The political importance of recognizing different conceptions of citizenship}

Did M adison County Youth in Public Service do a better job than BaysideStudents for Justice at educating citizens or was Bayside more effective? 0 ur goal is not to answer this question, but rather, to make clear that different democratic values were embedded in these efforts. Both programs were effective at achieving goals consistent with their respective underlying conceptions of citizenship. Yet our qualitative and quantitative data regarding these programs demonstrate important differences in impact. Youth in Public Service appeared to have a powerful impact on students' capacities for and commitments to civic participation. M easures of students' sense of personal responsibility to help others, their vision of how to help, and their leadership efficacy show significant changes. Especially notable in both the survey and interview data was the change in 
students' confidence that they had the knowledge or "social capital" to make things happen in the community. Interviews, observations, and examples of student work all reinforced the survey finding of a dramatic increase in students' sense that they had knowledge of what resources were available to help with community projects and of how to contact and work effectively with community organizations to mobilize those resources. This confidence grew out of their involvement in substantive projects that required frequent interaction with multiple community actors and agencies.

We did not, however, see evidence that the Youth in Public Service program sparked interest in or conveyed knowledge of broad social critiques and systemic reform. Since such issues were not discussed as part of the curriculum, it is not surprising that students' perspectives on the structural and individual causes of poverty, for example, did not change as a result of their participation. $\mathrm{N}$ or did their interest in talking about or being involved in politics change.

In comparison, the Bayside Students For Justice curriculum appeared to emphasize social critique significantly more and technocratic skills associated with participation somewhat less. To the extent that Bayside students learned about participatory skills, they focused on extra-governmental social activism that challenged rather than reinforced existing norms (such as community organizing or protesting). For example, students were more likely at the end of the program than at the beginning to posit structural explanations for social problems (stating, for example, that the problem of poverty resulted from too few jobs that pay wages high enough to support a family rather than being a result of individuals being lazy and not wanting to work). They were more likely than their $\mathrm{M}$ adison County peers to be interested in and want to discuss politics and political issues, and they were more likely to seek redress of root causes of difficult social ills. As one student told us after several months in the Bayside program, "when the economy's bad and people start blaming immigrants or whoever else they can blame, they've got to realize that there are big social, economic, and political issues tied together, that it's not the immigrants, no it's bigger than them."

Evidence from observations, interviews, student work, and surveys of Bayside's students did not, however, show an increase in students' knowledge about particular community resources. Unlike their M adison County peers, Bayside students' sense that they were effective community leaders (knowing how to run meetings, for example) remained unchanged. $\mathrm{N}$ or was there any increase in students' personal responsibility to help others (as opposed to their inclination for collective action for change that was frequently expressed during interviews).

The differing impact of these programs, of course, is likely due to factors that extend beyond the curriculum. As is generally the case in education, the broader social context helps to shape both the choice of curricular approaches adopted by the teachers and the ways these approaches impact students. Bayside and M adison C ounty are very different communities. It may well be that Bayside's urban school environment exposed students to more forms of injustice and rhetoric related to injustice than M adison County students encountered in their largely homogeneous and middle-class community. This exposure, in turn, may have made it more likely that Bayside students would gravitate towards justice oriented themes than that students from M adison County would do so. 
$M$ any other contextual factors may have mattered as well. Since the focus of our data collection emphasized curricular features and ways students experienced those features rather than on the broader social context, we cannot speak directly to these issues. Such issues are clearly worthy of extensive study.

\section{The politics of pursuing dual goals}

As noted earlier, those committed to educating social activists who practice justice oriented citizenship would ideally want to couple critical analysis of root causes of injustice with opportunities to develop capacities for participation. They want students to be able to both analyze and understand structural causes of deeply entrenched social problems and gain the skills and motivation to act by participating in local and national politics and community forums. But a focus on justice guarantees neither the motivation nor the capacity to participate in democratic change. $M$ any - ourselves included would applaud programs that manage to emphasize justice-oriented citizenship inextricably linked to a desire and capacity for participation. H owever, our findings indicate that the commitment to participation and the capacities it entails are not necessarily coupled with those related to the pursuit of social justice. Indeed, engaging in critical analysis does not necessarily foster the ability or the commitment to participate. The reverse is also true: students can learn to participate without engaging in critical analysis that focuses on macro structural issues, the role of interest groups, power dynamics, and/or social justice. The ability to spot injustice is not organically linked to the inclination or the ability to take action.

The relative emphasis placed on these differing goals will likely depend on numerous factors. These include: the structure of the curriculum, the priorities of those designing and implementing the initiative, and the time available for such instruction. M oreover, the political constraints and value based priorities of both administrators and community members are also likely to affect the structure of the curriculum.

Thus, answering the question "W hich program better develops citizens?" necessarily engages the politics that surround varied conceptions of citizenship. The relationship between pedagogical choices and political positions is an important one. Those who view civic participation as of primary importance would likely view the M adison County Youth In Public Service program as extraordinarily effective. $0 \mathrm{n}$ the other hand, those who believe that the pursuit of social justice is of paramount importance might well be troubled that participants in the M adison County program did not talk about the need for structural change, about methods used historically to bring change about (those employed by various social movements, for example), or about social injustice. Educators who wish to teach students to support social change might therefore value the explicit attention and critiques students participating in Bayside Students for Justice developed. Bayside students learned ways that the interests of powerful groups are often supported by institutions and social structures. They also expanded their interest in following broader local and national political issues. 


\section{Conclusion}

So, what does all of this mean for teaching democracy?

As educators interested in schooling's civic purposes, we maintain that it is not enough to argue that democratic values are as important as traditional academic priorities. We must also ask what kind of values. What political and ideological interests are embedded in varied conceptions of citizenship?

First, an initiative that supports the development of personally responsible citizens may not be effective at increasing participation in local and national civic affairs. M oreover, efforts to pursue some conceptions of personal responsibility can undermine efforts to prepare participatory and justice oriented citizens.

Second, our study of M adison C ounty Youth In Public Service and of Bayside Students for J ustice demonstrates the importance of distinguishing between programs that emphasize participatory citizenship and those that emphasize the pursuit of justice. W hile each program was effective in achieving its goals, qualitative and quantitative data regarding these programs demonstrated important differences in each program's impact. The study indicates that programs that champion participation do not necessarily develop students' abilities to analyze and critique root causes of social problems and visa versa. Although those committed to the democratic purposes of education may extol the value of linking priorities related to participation and justice, our study indicates that this outcome is not guaranteed. If both goals are priorities, those designing and implementing curriculum must give both explicit attention.

Third, from the standpoint of research and evaluation, the implications for those interested in the development of democratic values and capacities are significant. Studies that fail to reflect the varied range of educational priorities in relation to democratic values and capacities will tell only part of the story.

We can focus on whether a given curriculum changes students' sense of personal responsibility, government responsibility, or employer responsibility, for example. If we ask only about personal responsibility, we may well be reinforcing a conservative and individualistic notion of citizenship, that of the personally responsible citizen. Yet this is the focus of many programs and of their associated evaluations. If citizenship also requires collective participation and critical analysis of social structures, then other lenses are needed as well.

Those designing curriculum and those studying its impact must be cognizant of and responsive to these important distinctions and their political implications. The choices we make have consequences for the kind of society we ultimately help to create.

The research described in the article was generously supported by two grants from the Surdna Foundation. 


\section{Notes}

1. For a description of a contemporary curriculum that reflects this emphasis, see Westheimer and Kahne (2002).

2. O ur desire to respond to prominent educational theories related to democratic ideals and to develop a framework that practitioners would find both clear and meaningful led us to modify our categories in several ways. For example, we began this study emphasizing a distinction between "charity" and "change". We had used this distinction in earlier writing (Kahne\& Westheimer, 1996). T hrough the course of our work, however, it became clear that this distinction did not do enough to capture main currents in dial ogues of practitioners and scholars regarding democratic educational goals and ways to achieve them (see also Westheimer \& Kahne, 2000). In addition, once our three categories were identified, we found that some of our rhetoric failed to clearly convey our intent. For example, we had initially titled our third category the "social reconstructionist." As a result of dialogues with practitioners this was changed to the "social reformer" and finally to the "justice oriented citizen."

$\dagger$ For help in structuring this table, we are indebted to James Toole and a focus group of M innesota teachers.

\section{References}

Ayers, W., H unt, J. A., and Q uinn, T. (Eds.) (1998). Teaching for social justice. N ew York: The $\mathrm{N}$ ew Press and Teachers $\mathrm{C}$ ollege Press.

Barber, B. (1984). Strong democracy: Partici patory politics for a new age. Berkeley: University of California Press.

Bennett, W.J. (1985). Education for democracy. Paper presented at the regular meeting of the Consejo Interamericano para la Education, la Ciencia, y la Cultura. Washington, D.C.

Bennett, W. J. (Ed.) (1995). The M oral compass: Storiesfor a lifés journey. N ew York: Simon \& Schuster. "C itizenship and Leadership" section.

Bennett, W. J. (1998). The place to harvest patriots. School Administrator, 55(5), 38-40.

Bennett, W. J., Cribb, J.T., and Finn, C.E. (1999). The educated child. N ew York: Free Press. "Character Education" section (pp.523-539).

Bigelow, W. and D iamond, N . (1988). The power in our hands. A curriculum on the history of work and workersin the U nited States. N ew York: M onthly Review Press.

Boyte, H . C . and Kari, N . N . (1996). Building America: The democratic promise of public work. Philadel phia: Temple U niversity Press.

Bush, G.W. (2001). President Bush launches effort to bring students and veterans together in America's classrooms: Education and veterans affairs team up to promote "Lessons of Liberty." U .S. D epartment of Education press release, 0 ct. 30. www.ed.gov/PressR eleases/10-2001/ 10302001.html

Butts, R.F. (1988). T he moral imperative for American schools: "I nflame the civic temper." American Journal of Education, 96(2), 162-94.

C onnolly, W.E. (1983). Theterms of political discourse. 2nd ed. Princeton, N J : Princeton University Press.

C ounts, G . (1932). D are progressive education be progressive? ProgressiveE ducation, 9, 257-63.

C haracter Counts (1996). C haracter counts. Los Angeles: Character Counts! C oalition.

D ewey, J. (1916). D emocracy and education. N ew York: The Free Press.

D udley, R. L. and Gitelson, A. R. (2002). Political literacy, civic education, and civic engagement: A return to political socialization? Applied D evelopmental Science, 6(4), 175-182.

Freire, P. (1985). The politics of education: Culture, power and liberation. South $\mathrm{H}$ adley, M A: Bergin \& G arvey Publishers. 
Freire, P. (1970). Pedagogy of the oppressed. Translated by M yra Bergman Ramos. N ew York: $\mathrm{H}$ erder \& Herder.

Goodman, J. (1992). Elementary schooling for democracy. Albany, N Y: State U niversity of N ew York Press.

H anna, P. R. (1936). Youth servesthe community. N ew York: D. Appleton-C entury.

Isaac, K. (1992). Civics for democracy: T he journey for teachers and students. (A project of the Center for Study of Responsive and Essential Information). Washington D .C.: Essential Books.

Kaestle, C.F. (2000). Toward a political economy of citizenship: H istorical perspectives on the purposes of common schools. In L. M cD onnell, P.M. Timpane, \& R. Benjamin (Eds.), Redi scovering the democratic purposes of education (47-72). Kansas: U niversity Press of Kansas.

Kahne, J. and Westheimer, J. (1996). In the service of what?T he politics of service learning. Phi Delta Kappan, 77(9), 593-599.

Lickona, T. (1993). The return of character education. Educational Leadership, 51(3), 6-11.

M ann, H . (1838). First annual report. Boston: D utton \& Wentworth.

M iller, D . (1995). Citizenship and pluralism. Political Studies, 43(3), 432-450.

$\mathrm{N}$ ational Association of Secretaries of State (1999). N ew millennium project-phase I: A nati onwide study of 15-24 year old youth. Alexandria, VA: theTarrance G roup.

Niemi, R. G . and Junn, J. (1998). Civic education: What makes students learn. N ew H aven: Yale University Press.

N ewmann, F. (1975). Education for citizen action: C hallenge for secondary curriculum. Berkeley, CA: M cCutchan Publishing Corporation.

Pangle, L. S. and Pangle, T. L. (1993). Thelearning of liberty. K ansas: University Press of K ansas.

Parker, W. (1996). 'Advanced' ideas about democracy: Toward a pluralist conception of citizen education. Teachers College Record, 98(1), 104-125.

Points of Light Foundation website (2003). http://www. pointsoflight.org.

Putnam, R. D . (1993). M aking democracy work: Civic traditionsin modern Italy. Princeton: Princeton University Press.

Putnam, R. D . (2000). Bowling al one: The collapse and revival of American community. N ew York: Simon \& Schuster.

Rugg, H . O . (1921). Reconstructing the curriculum: An open letter to Professor H enry Johnson commenting on committee procedure as illustrated by the Report of the Joint Committee on $\mathrm{H}$ istory and Education for C itizenship. H istorical O utlook, 12, 184-189. Reprinted in Parker, W. C. (Ed.) (1996). Educating the democratic mind. Albany, N Y: State U niversity of N ew York Press (pp. 45-60).

Saguaro Seminar (2000). Report of the Saguaro Seminar: Civic engagement. Boston, M A: Saguaro Seminar.

Sax, L. J., Astin, A., Korn, W. S., and M ahoney, K. (1999). The American freshman: N ational norms for fall 1999. Los Angeles: H igher Education Research Institute, U CLA.

Schudson, M . (1998). T he good citizen: A history of American civic life. N ew York: Free Press.

Shanker, A. (1986). Education and democratic citizenship. Speech to meeting of the American Federation of Teachers. Q uoted in Shanker, A. (1997). Education and democratic citizenship: where we stand. International Journal of Social Education, 12, 1-10.

Shor, I. (1992). Empowering education: C ritical teaching for social change. Chicago: University of Chicago Press.

Smith, R. M . (1997). Civic ideals: Conflicting visions of citizenship in U.S. history. N ew H aven, CT: Yale University Press.

Soder, R., Goodlad, J. I., and M cM annon, T. J. (Eds.) (2001). D eveloping democratic character in the young. San Francisco: Jossey-Bass.

Tarcov, N. (1996). The meanings of democracy. In R. Soder (Ed.), D emocracy, education, and the schools (pp.1-36). San Francisco: Jossey-Bass. 
Verba, S. Schlozman, K. L., and Brady, H . E. (1995). Voiceand equality: Civic volunteerism in American politics. C ambridge: $\mathrm{H}$ arvard U niversity Press.

Westheimer, J. and Kahne, J. (2002). Educating for democracy. In R. H ayduk \& K. M attson (Eds.), D emocracys moment: Reforming the American political system for the $21^{\text {td }}$ century (pp.91-107). Lanham, M D : Rowman \& Littlefield.

Westheimer, J. and Kahne, J. (2000). Service learning required - but what exactly do students learn? Education Week, January 26. Back Page Commentary (pp. 42).

Wynne, E. A. (1986). The great tradition in education: Transmitting moral values. Educational Leadership, 43(4), 4-9. 